« Financial market imperfections and monetary policy strategy "

\author{
$\underline{\text { Auteurs }}$ \\ Meixing Dai \\ Document de Travail n 2010 - 19
}

Juillet 2010

Faculté des sciences économiques et de gestion

Pôle européen de gestion et d'économie (PEGE) 61 avenue de la Forêt Noire F-67085 Strasbourg Cedex

Secétariat du BETA Géraldine Manderscheidt Tél. : (33) 0368852069 Fax : (33) 0368852070 g.manderscheidt@unistra.fr http://cournot2.u-strasbg.fr/beta 


\title{
Financial market imperfections and monetary policy strategy
}

\author{
Meixing DAI \\ BETA, University of Strasbourg, France
}

\begin{abstract}
In a model with imperfect money, credit and reserve markets, we examine if an inflation-targeting central bank using the funds rate operating procedure to indirectly control market interest rates also needs a monetary aggregate as policy instrument. We show that if private agents use information extracted from money and financial markets to form inflation expectations and if the access to liquidity is subject to non-price rationing, the central bank can use a narrow monetary aggregate and the discount interest rate as independent policy instruments to reinforce the credibility of its announcements and the role of inflation target as nominal anchor for inflation expectations. This study shows how a monetary policy strategy combining inflation targeting and monetary targeting can be conceived to guarantee macroeconomic stability and the credibility of monetary policy. Friedman's $k$-percent money growth rule, generating dynamic instability, and two alternative stabilizing feedback monetary targeting rules are examined.
\end{abstract}

Key words: Imperfect financial markets, non-price rationing, inflation targeting, monetary targeting, macroeconomic stability, Friedman's $k$-percent rule, feedback money growth rules, two-pillar strategy.

JEL Classification: E44, E52, E58

\section{Corresponding address:}

BETA, University of Strasbourg, 61, avenue de la Forêt Noire - 67085 Strasbourg Cedex France. Phone: (33) 03688521 31; Fax: (+33) 03688520 71; E-mail: dai@unistra.fr.

Acknowledgments: I am grateful to Gilbert Koenig and Eleftherios Spyromitros for helpful comments and discussions. 


\section{Introduction}

Over the last decade, more and more central banks have adopted a new framework for conducting monetary policy known as inflation targeting, which is presented by Mishkin (1999) as a successor to and more efficient in controlling inflation than monetary targeting. In this context, the two-pillar monetary policy strategy of the ECB, announced in the autumn of 1998, appears quite singular and quickly becomes controversial.

Political considerations, i.e. the need to demonstrate continuity with the policies of the Bundesbank, have apparently dictated that the ECB pays attention to monetary aggregates as well in its two-pillar monetary policy strategy. In practice, the Bundesbank was a monetary targeter as well as an inflation targeter. ${ }^{1}$ For some researchers, the Bundesbank's success can be explained by the fact that its monetary targeting is quite similar to inflation targeting as it announced inflation target and transparently communicated to the public and market participants. $^{2}$ In doing so, its monetary policy is closer in practice to inflation targeting than it is to Friedman-like monetary targeting and thus might best be thought of as "hybrid" inflation targeting. Therefore, many observers have interpreted the ECB's two-pillar strategy as a bridge between the monetary targeting strategy of the old Bundesbank and the more up-to-date inflation targeting approach (Bernanke et al., 1999; Svensson, 2000; Rudebusch and Svensson, 2002; Mayer, 2006). In effect, the "economic pillar" resembles an implicit form of inflation targeting and the "monetary pillar" a weak type of monetary targeting. However, according to Assenmacher-Wesche and Gerlach (2007), this is a "misinterpretation" which has lead to the criticism of the framework for being inconsistent and lacking clarity.

\footnotetext{
${ }^{1}$ Gerberding et al. (2005) find that the Bundesbank took its monetary targets seriously, but also responded to deviations of expected inflation and output growth from target.

2 See, e.g., Clarida and Gertler (1996), Bernanke and Mishkin (1997), Bernanke and Mihov (1997), Laubach and Posen (1997), and Clarida et al. (1998).
} 
The disagreement among economists about the true nature of the two-pillar strategy is arguably due to the fact that the ECB provides neither an explicit representation of the inflation process nor an explanation for why it necessitates a two-pillar framework. In effect, it lacks a theory justifying the simultaneous use of monetary targeting and inflation targeting.

While monetary targeting has a clear theoretical foundation and some successful experiences, the two-pillar monetary strategy lacks solid theoretical foundations and is at odd with the current consensus about the best monetary policy strategy, i.e. inflation targeting. According to this consensus, if the central bank controls the nominal interest rate, inflation expectations are independent of monetary aggregates. Furthermore, the duality problem in a simple New-Keynesian or traditional IS-LM model implies that we can either control money supply or nominal interest rate but not two of them at the same time.

Most of recent studies have suggested the rejection of onetary targeting on the basis that it is less efficient than inflation targeting (e.g., Rudebusch and Svensson, 2002; Evans and Honkapohja, 2003; Woodford, 2008) or that the instability of the relationship between monetary aggregates and goal variables implies too many conditions for its success (Mishkin, 1999) and larger control problems (Cabos et al., 2003). However, when this relationship is unstable, a central bank with high credibility can successfully stabilize inflation and output through monetary targeting if it is flexible, transparent and accountable (Mishkin, 2002).

Several authors provide empirical models with two-pillar Phillips curve which justifies the two-pillar strategy (e.g. Gerlach, 2004; Assenmacher-Wesche and Gerlach, 2007) by testing the hypothesis that inflation can be decomposed into a 'trend', which is explained by a smoothed measure of past money growth, and a deviation from that trend, which is accounted for by the output gap. Based on Ireland (2004), Barthélemy et al. (2008) have developed a DSGE monetary policy model for the Euro Area in which both the IS and Phillips curves depend on real balances. They have found a significant role for money in the Euro Area. These 
studies imply that the optimal interest rate rule depends on money growth. Hence, inflation expectations are related to monetary aggregates even if only information extracted from the optimal inflation targeting rule, Phillips curve and IS curve is used to form them.

Other arguments in favour of an ECB-style two-pillar strategy does not require direct effects of money on output or inflation. Bordes and Clerc (2007) justify the need to announce a monetary growth target (reference value) by arguing that the central bank can influence the real interest rate through the liquidity effect in the short term but not in the medium to long term. Therefore, in order to reduce long-term price level uncertainty and to ensure the consistency between short-term and long-term inflation expectations, its only means of action to influence inflation expectations is through the announcement of a money growth target. Beck and Wieland (2007) have shown that, in the event of persistent policy misperceptions regarding potential output, the ECB-style cross-checking and changing interest rates in response to sustained deviations of long-run money growth can have some stabilisation properties. Woodford (2008) also argues that, to the extent that money growth is useful as an indicator variable, there is no a priori reason to exclude monetary variables from the set of indicators that are taken into account by the central bank.

The recent financial crisis of 2007-09 has lead De Grauwe and Gros (2009) to contest the consensus according to which the price stability is a strategy that will minimise the risk of financial instability and the main responsibility for maintaining financial stability is in the hands of the supervisors and regulators. ${ }^{3}$ Considering that there is a trade-off between price stability and financial stability, they suggest that the ECB would continue to use the interest rate to achieve its inflation target while using reserve requirements and macro-prudential

\footnotetext{
${ }^{3}$ They agree with the emerging consensus that price stability does not guarantee financial stability and is, in fact, often associated with excess credit growth and emerging asset bubbles (see, e.g., M. King, 2009; Shirakawa, 2009).
} 
controls to maintain financial stability. Thus, the ECB would have an instrument to prevent asset bubbles from getting out of hand, which should stabilise inflation expectations.

The above studies relative to the two-pillar monetary policy strategy neglect one important assumption which justifies the opposition between monetary targeting and inflation targeting. In effect, under the assumption that all financial assets are perfect substitutes and hence interest rates on money and credit markets are perfectly controlled by the central bank, these two strategies become substitutable. By recommending the control of nominal interest rate, economists advocate that the supply of money is automatically determined by the demand (Woodford, 1998; Rudebusch and Svensson, 1999). It implies that the monetary authority implicitly confers to the private sector the following message: any quantity of money that you wish at given nominal interest rate will be provided. In a reduced macro-economic model (New-Keynesian or traditional IS-LM model) which simplifies at maximum the functioning of money and financial markets, the strategy of inflation targeting is efficient and allows anchoring inflation expectations when the central bank is perfectly credible and transparent. However, one can question whether, in practice, financial institutions and other private agents have an unconstrained access to the central liquidity and whether they doubt about the inflation expectations anchoring when the central bank is not perfectly credible and transparent.

It is to notice that, since the end of $1980 \mathrm{~s}$, most central banks (including inflationtargeting central banks) target only indirectly market interest rates through a funds rate targeting procedure (Walsh, 2003). Under such an operating procedure, the central bank, by setting the discount interest rate, conducts open-market operations to target the funds rate, a very short interest rate on the interbank market. The literature on the inflation targeting and interest rate rules greatly simplifies the theoretical models by not distinguishing these interest 
rates with other market interest rates (e.g., longer term interbank interest rate, medium and long term lending rates), which directly affect private consumption and investment.

As Romer (2000) has remarked, one area in which both the traditional IS-LM approach (where the money is considered as a monetary policy instrument) and IS-MP approach (where MP stands for monetary policy, i.e. interest rate rule or inflation targeting) may have simplified too far in their treatment of financial markets. In both approaches, the only feature of financial markets that matters for the demand for goods is 'the' real interest rate that monetary policy can powerfully and directly influence as the central bank desires. In practice, the demand for goods depends on interest rates that the central bank may not be able to control directly as well as the level of credit which is available at those rates. An analysis, which more carefully takes account of the impacts of various developments in financial markets on the demand for goods as well as the mechanism through which the monetary policy affects these interest rates and the level of credit, would highlight many of the difficulties and uncertainties of actual policy-making. For B. Friedman (2003), abandoning the role of money and the analytics of the LM curve makes it less easy to explain how the functioning of the banking system (and with it the credit markets more generally) matters for monetary policy and also leaves open the underlying question of how the central bank manages to fix the chosen interest rate in the first place. These concerns find some echoes in Goodhart (2007) who argues that the central banks must still pay attention to the monetary aggregates, in particular the growth rate of the bank credit allocated to the private sector. Moreover, Christiano et al. (2007) show that a monetary policy which concentrates too narrowly on inflation can, in an unintended way, contribute to reduce the welfare via cycles of expansion and depression in the real and financial variables. More recently, Walsh (2009) observes that distortions in financial markets and financial shocks that generate real effects of monetary policy also imply that financial stability may require making trade-offs between inflation stabilization and output stabilisation. 
This paper examines how the monetary policy strategy of a central bank that, under a funds rate targeting procedure, indirectly controls market interest rates through setting the discount interest rate and conducting open-market operations, will be affected by the alternative assumptions about the transmission mechanism of monetary policy. More precisely, we assume that money, credit and reserve markets are imperfect and private agents also use information extracted from equilibrium conditions on these markets in forming their inflation expectations. Under these assumptions, inflation expectations depend on the money growth rate. Thus, manipulating the money supply, while setting the discount rate, could be a sensible monetary policy strategy. The principal aim of this study is to show how to combine inflation targeting and monetary targeting in order to anchor inflation expectations and to ensure the dynamic stability of the economy when the impacts of monetary and financial factors on monetary policy strategy are taken into account.

In practice, the central liquidity is not accessible at unlimited quantity because central banks limit the quantity, quality and types of assets accepted as collateral as well as the types of financial institutions which have direct access to this liquidity, i.e. there is non-price rationing. This implies that there could be a potential imbalance (excess of liquidity or crisis of illiquidity) on the money market. Thus, setting the discount rate under the funds rate operating procedure does not allow a strict control of interest rates on money and credit markets as shown by their dramatic rise in the wake of the bankruptcy of Lehman's Brothers in the fall of 2008.

Central bank's interventions through injection or withdrawal of liquidity become essential for bringing market interest rates to a level near the discount rate, which normally anchors the expected market interest rates but has not the power of controlling their actual levels. The control of money supply also has the advantage of being more flexible than that of the discount rate because the latter must generally follow a well defined trend and is not 
modifiable within long intervals separating two interest policy decisions except in the event of financial crisis.

In effect, the hypothesis of imperfect money and financial markets offers a better understanding of the functioning of the economy and how a monetary policy is implemented. In effect, the target of credit market's interest rate (determined by the central bank and formulated in terms of optimal interest rate rule under the inflation-targeting regime), which directly affects the decision of consumption and investment, cannot be directly set and is not always realized due to the malfunctioning of money and financial markets or shocks affecting these markets. More precisely, the central bank sets the discount rate, which is determined by taking account of inflation and output targets as well as the complete economic model (including money and financial markets). A modification of the discount rate allows inducing a change in the money market interest rate, affecting then the interest rate determined on the credit market at which firms and consumers can borrow. If this transmission mechanism is perturbed by exogenous shocks or endogenous instability, adopting monetary targeting under inflation-targeting regime through the design of appropriate interest rate rule and money growth rule could have many advantages in terms of monitoring inflation expectations, controlling money and credit market interest rates, and ensuring the dynamic stability of the economy.

The failure of the transmission mechanism, which links the discount rate to other interest rates as well as the zero bound on the nominal interest rate, could greatly limit the possibility of actions for inflation-targeting central banks. In severe economic and financial crises, a central bank too aggressive in reducing the discount rate can quickly find itself without interest rate instrument and therefore the means of sufficiently reducing money and credit market interest rates and anchoring inflation expectations. 
In this respect, this paper is also related to the literature on the zero bound on the nominal interest rate and quantitative easing policy. It is to notice that, theoretical studies about the zero bound on the nominal interest rate (e.g. Svensson, 2001; Benhabib et al., 2002; Eggertsson and Woodford, 2003; Auerbach and Obstfeld, 2005; Adam and Billi, 2007), using a framework similar to the one employed by the literature on inflation targeting, do not make explicit the links between monetary policy and extremely negative financial shocks and hence are not wholly satisfactory for studying the underlying transmission mechanism of the effects of zero-interest and quantitative-easing policies. In this respect, the present framework can be easily extended to take into account this kind of link and hence allows understanding why these policies becomes suddenly necessary under extreme financial stress.

The hypothesis of imperfect money and financial markets also gives a better account of the dynamics of inflation expectations. The expected inflation rate deduced from the spread of return between the indexed and un-indexed bonds shows that inflation expectations are not as static as predicts the inflation targeting literature. ${ }^{4}$ Thus, using information extracted from money and financial markets could improve private sector's inflation expectations compared to the case where only information extracted from the interest rate rule, the Philips curve and the IS curve is used as it is admitted in the literature on inflation targeting and interest rate rules.

In the following, a narrow monetary aggregate and the discount interest rate are considered as two independent but complementary monetary policy instruments. Well used simultaneously, they allow preventing macroeconomic and financial instability in an uncertain economic environment. Their combination can be considered as a kind of two-pillar monetary policy strategy. However, it is not simply the reintroduction of the monetarism in the inflation-

\footnotetext{
4 Some introductive teachings even treat the expected rate of inflation as fixed in the presence of serially noncorrelated stochastic shocks (Romer, 2000; Walsh, 2002).
} 
targeting framework through the adoption of Friedman's $k$-percent money growth rule. In effect, the design of money growth rules is crucial for the success of such strategy.

The remainder of the paper is organized as follows. The next section presents a theoretical model with imperfect money and financial markets. In the section after, the optimal reaction function of the central bank is derived by taking into account the imperfection of money and financial markets. The fourth section considers the reduced model and derives the dynamic equation for expected inflation rate. The fifth section analyzes the dynamic stability of the economy under Friedman's $k$-percent money growth rule. The sixth section examines two alternative feedback monetary targeting rules. The final section summarizes the findings.

\section{The Model}

The economy is characterized by a continuous time model. Equations describing inflation adjustment, aggregate spending and money market equilibrium are given as follows: 5

$$
\begin{array}{ll}
\pi_{t}=\pi_{t}^{e}+\alpha\left(y_{t}-y^{*}\right)+\varepsilon_{\pi t}, & \alpha>0, \\
y_{t}=-\beta\left(i_{c t}-\pi_{t}^{e}\right)+\varepsilon_{d t}, & \beta>0, \\
m_{t}-p_{t}=l_{1} y_{t}-l_{2} i_{m t}+\varepsilon_{l t}, & l_{1}, l_{2}>0,
\end{array}
$$

where $\pi_{t}\left(\equiv \frac{d p_{t}}{d t} \equiv \dot{p}_{t}\right)$ is the current inflation rate which is the time derivative of general price level $p_{t}, \pi_{t}^{e}$ the unconditional expected inflation rate of time $t, y_{t}$ the actual output, $y^{*}$ the natural rate of output, $i_{c t}$ the nominal credit market interest rate at which banks lend to nonfinancial private agents, $i_{m t}$ a medium-term nominal interest rate on the interbank money market and $m_{t}$ the money supply. The variables $y, m$ and $p$ are expressed in natural

\footnotetext{
5 We can also use a standard micro-founded New-Keynesian framework (Clarida et al., 1999) by integrating some imperfections on money and financial markets for the purpose of policy analysis.
} 
logarithms. $\varepsilon_{\pi t}, \varepsilon_{d t}$ and $\varepsilon_{l t}$ are respectively contemporary stochastic shocks affecting the supply and the demand of goods and the demand of money.

Equation (1) stipulates that inflation adjustment is governed by an expectational Phillips curve. According to equation (2), the aggregate demand depends on expected real interest rate on the credit market, $i_{c t}-\pi_{t}^{e}$. Equation (3) represents the LM curve with a real money demand depending on real income and nominal money market interest rate.

The money supply is endogenous but imperfectly elastic as the banking system will increase or decrease the internal money in taking account of nominal interest rate as well as collateral and will not always satisfy the money demand. Similarly, the central bank provides a limited quantity of central liquidity on the reserve market to a limited number of banks by accepting certain categories of assets as collateral. The link between the total money supply and the monetary base is modeled as follows:

$$
m_{t}=b_{t}+h_{1} i_{m t}+\omega_{t}, \quad h_{1}>0 \text {. }
$$

where $b_{t}$ is the monetary base in log terms, and money multiplier $\left(m_{t}-b_{t}\right.$ in log terms) is assumed to be an increasing function of nominal money market interest rate, and $\omega_{t}$ is a money-multiplier disturbance. The modeling of money supply is similar to that of Modigliani et al. (1970), and McCallum and Hoehn (1983).

The central bank is assumed to indirectly target the money and credit market interest rates through the funds rate targeting procedure. Under such an operating procedure, the central bank does not directly target $i_{c t}$ or $i_{m t}$, longer term interest rates, but the funds rate $\left(i_{f t}\right)$, a very short-run or overnight interest rate. In effect, the central bank controls the discount rate, $i_{d t}$, and conducts open market operations to affect the supply of reserves in the banking system to target the funds rate. It is assumed that there is non-price rationing of access to the central 
liquidity at the discount window, so that $i_{f t} \neq i_{d t} \cdot{ }^{6}$ Similarly, it is assumed there is non-price rationing of access to inside liquidity created within the banking and financial system so that we generally have $i_{m t} \neq i_{f t} \neq i_{d t}$.

Under the funds rate targeting procedure, using a simplified description of the reserve market to establish the link between the monetary base $b_{t}$ and the discount rate $i_{d t}$, the money supply can be rewritten as (Appendix A)

$$
m_{t}=\bar{b}_{t}+h_{1} i_{m t}-h_{2} i_{d t}+\varepsilon_{m t}, \quad h_{1}, h_{2}>0
$$

where $\bar{b}_{t}$ represents the currency in log terms but could also include the component of the reserves that the central bank can discretionarily control by adjusting the ratio of obligatory reserves, and $\varepsilon_{m t}$ represents shocks affecting the monetary base under the funds rate targeting procedure as well as these affecting the monetary multiplier. According to equation (5), the central bank, by controlling the discount rate, has not a strict control over the money supply since the latter is affected by the money market interest rate and a random shock. However, in order to modify the behaviors of private agents and their inflation expectations, control can be exercised by the central bank over $\bar{b}_{t}$, a component of monetary base which do not depend on the discount rate. The equilibrium condition on the money market (3) is rewritten as

$$
\bar{b}_{t}+h_{1} i_{m t}-h_{2} i_{d t}+\varepsilon_{m t}-p_{t}=l_{1} y_{t}-l_{2} i_{m t}+\varepsilon_{l t},
$$

In the following, we assume that $h_{1}-h_{2}+l_{2}>0$. This is justified on the ground that the supply of liquidity by the banking sector is more likely determined by the difference $\left(i_{m t}-i_{d t}\right)$, i.e. the net gain obtained from providing more liquidity while refinancing it at the discount rate. Thus,

\footnotetext{
${ }^{6}$ If there were no nonprice rationing at the discount window, the funds rate would never rise above the discount rate, because a bank would never pay more for reserves than it would have to pay at the discount window (Goodfriend, 1983).
} 
an increase of equal amount in $i_{d t}$ and $i_{m t}$ will not (or modestly) affect the money supply but will significantly reduce the money demand, ceteris paribus.

The model is completed by a credit market equilibrium condition in the spirit of Bernanke and Blinder (1988):

$$
-f_{1} i_{m t}+f_{2} i_{c t}=j_{1} y_{t}-j_{2} i_{c t}+\varepsilon_{c t}, \quad \text { with } f_{1}, f_{2}, j_{1}, j_{2}>0
$$

where $\varepsilon_{c t}$ denotes a random shock that incorporates both credit supply and credit demand shocks. We admit that $f_{1}-f_{2}-j_{2}<0$, i.e. an increase of identical amount in $i_{m t}$ and $i_{c t}$ will leave the credit supply stable or decreasing less (as the lending margin in absolute terms is unchanged and only the margin in relative terms is reduced) than the credit demand. Some modifications relative to the model of Bernanke and Blinder have been introduced. Public bonds are not included in this model since its rate of return could stay relatively stable in the event of important financial shocks affecting private sectors. The private bonds are assumed to be a perfect substitute to bank lending. Instead of long term bonds, the rate of interest $i_{m t}$ is assumed to affect both the demand and supply of liquidity on the money market. For simplicity, we further assume that $i_{m t}$ does not affect consumption and investment decisions. Despite these simplifications, by giving a special attention to money and credit markets, we can quite realistically examine how the central bank's interest rate policy makes its way into the economy and how inflation expectations adjust.

Since financial assets are imperfect substitutes, their respective interest rates are related by the following no-arbitrage conditions at equilibrium:

$$
\begin{aligned}
& i_{c t}=i_{m t}+\rho_{c t}, \\
& i_{m t}=i_{d t}+\rho_{m t} .
\end{aligned}
$$


where $\rho_{c t}$ is the sum of the mark-up and a risk premium over money market interest rate applied by banks to the commercial lending, $\rho_{m t}$ is a risk premium over the discount rate applied to the interbank lending.

When the central bank controls $i_{d t}$, it must recursively determine the target of $i_{d t}$ using equations (6)-(7) or (8)-(9) once the target of credit market interest rate is known. Thus, given that the money market equilibrium condition (6) determines the value for $i_{d t}$ to attain the targets of other interest rates, it follows that the money supply cannot be endogenously determined using the same condition as it is usually assumed in the inflation targeting literature (Woodford, 1998, Clarida et al., 1999; King, 2000).

The way to close the model generally adopted in the inflation-targeting literature is to assume that the money supply automatically adjusts to the money demand so that the money market can be ignored without serious consequences. In this model, by assuming that market interest rates and discount rate are distinct, the central bank will not be able to control the market interest rates without manipulating the money supply. In other words, the money supply is partially endogenous but does not automatically adjust to satisfy the money demand except when the central bank maintains $\rho_{m t}$ at a fixed level.

The central bank acts to minimize fluctuations of output around the natural rate and inflation around its target under discretion. More precisely, the central bank is assumed to minimize the following loss function measured in terms of present discounted value:

$$
L=\int_{0}^{\infty} \frac{1}{2}\left[\lambda\left(y_{t}-y^{*}\right)^{2}+\kappa\left(\pi_{t}-\pi^{T}\right)^{2}\right] \exp (-\theta t) d t, \quad \lambda, \kappa, \theta>0
$$

where parameters $\lambda$ and $\kappa$ denote the weight that the central bank assigns to output and inflation stabilization respectively, and $\theta$ is the discount factor. The strategy of flexible 
inflation targeting is implemented through an optimal nominal interest rate rule, which is deduced from the optimal inflation targeting rule of the central bank.

The time sequence of events is as follows: 1) Workers form their inflation expectations and negotiate current wages taking account of information about the economy, including that extracted from observing the money and financial markets. 2) Shocks realize. 3) The central bank sets the discount rate following an optimal interest rate rule as well as the money growth rate. 4) Firms decide their production and prices.

\section{The optimal interest rate rules}

The optimal inflation targeting rule is the solution to the sequence of single period decision problems of the central bank under discretion. Because the decisions of the central bank at time $t$ do not bind it at any future dates, the central bank is unable to affect the private sector's expectations about future inflation. Thus, for given inflation expectations, the decision problem of the central bank becomes the problem of minimizing the single-period loss function in (10) subject to the inflation adjustment equation (1). Thus, the first-order condition for this problem is:

$$
y_{t}=y^{*}-\frac{\kappa \alpha}{\lambda}\left(\pi_{t}-\pi^{T}\right)
$$

that, with equation (2), leads to the following optimal credit market interest rate rule:

$$
i_{c t}^{T}=\pi_{t}^{e}+\frac{1}{\beta}\left[\frac{\kappa \alpha}{\lambda}\left(\pi_{t}-\pi^{T}\right)-y^{*}+\varepsilon_{d t}\right]
$$

where $i_{c t}^{T}$ represents the target of credit market interest rate at $t$, which must be attained in order to minimize the central bank's loss function.

According to equation (12), it is optimal for the central bank to adjust the target of nominal credit market interest rate upward to reflect the expected inflation rate (to a full extent), the 
gap between current inflation and the inflation target, a decrease in the natural rate of output as well as positive demand shocks.

Definition: An inflation targeting regime is a monetary strategy under which the central bank directly sets the short-run interest rate so that the target of credit market interest rate defined by the rule (12) is realized without being altered by the imperfections and shocks affecting the money and financial markets.

To attain the target of credit market interest rate, the central bank controls only directly the discount rate, which indirectly affects the credit market interest rate via the money market interest rate. The latter's target, $i_{m t}^{T}$, is related to $i_{c t}^{T}$ through equation (7). Using equations (7) and (11)-(12), it follows:

$$
\begin{aligned}
i_{m t}^{T} & =-\frac{j_{1}}{f_{1}}\left[y^{*}-\frac{\kappa \alpha}{\lambda}\left(\pi_{t}-\pi^{T}\right)\right]+\frac{f_{2}+j_{2}}{f_{1}} \overbrace{\left\{\pi_{t}^{e}+\frac{1}{\beta}\left[\frac{\kappa \alpha}{\lambda}\left(\pi_{t}-\pi^{T}\right)-y^{*}+\varepsilon_{d t}\right]\right\}}^{i_{c t}^{T}}-\frac{1}{f_{1}} \varepsilon_{c t} \\
& =\frac{f_{2}+j_{2}}{f_{1}} \pi_{t}^{e}+\frac{f_{2}+\beta j_{1}+j_{2}}{\beta f_{1}}\left[\frac{\kappa \alpha}{\lambda}\left(\pi_{t}-\pi^{T}\right)+y^{*}\right]+\frac{f_{2}+j_{2}}{\beta f_{1}} \varepsilon_{d t}-\frac{1}{f_{1}} \varepsilon_{c t} .
\end{aligned}
$$

According to equations (12) and (13), $i_{m t}^{T}$ reacts more strongly, compared to $i_{c t}^{T}$, to the expected inflation rate and demand shocks if $\frac{j_{2}+f_{2}}{f_{1}}>1$, and it reacts more strongly to the gap between the inflation rate and the inflation target and the natural rate of output if $\frac{\beta j_{1}+j_{2}+f_{2}}{f_{1}}>1$, and vice versa.

Proposition 1. To implement the inflation-targeting regime, the target of money market interest rate must be adjusted to neutralize the effects of credit demand and supply shocks on the credit market interest rate.

Proof. It follows directly from comparing equations (12) and (13).

The discount rate must be set such that the target of money market interest rate is attained. Setting $i_{m t}=i_{m t}^{T}$ and using equations (6), (11) and (13) yield 


$$
\begin{aligned}
i_{d t}^{T}= & \frac{1}{h_{2}} \bar{b}_{t}+\frac{h_{1}+l_{2}}{h_{2}}\{\overbrace{\frac{f_{2}+j_{2}}{f_{1}} \pi_{t}^{e}+\frac{f_{2}+\beta j_{1}+j_{2}}{\beta f_{1}}\left[\frac{\kappa \alpha}{\lambda}\left(\pi_{t}-\pi^{T}\right)-y^{*}\right]+\frac{f_{2}+j_{2}}{\beta f_{1}} \varepsilon_{d t}-\frac{1}{f_{1}} \varepsilon_{c t}}^{i_{m t}^{T}}{ }\} \\
& -\frac{l_{1}}{h_{2}}\left[y^{*}-\frac{\kappa \alpha}{\lambda}\left(\pi_{t}-\pi^{T}\right)\right]-\frac{1}{h_{2}} p_{t}+\frac{1}{h_{2}}\left(\varepsilon_{m t}-\varepsilon_{l t}\right) \\
= & \frac{\left(h_{1}+l_{2}\right)\left(f_{2}+j_{2}\right)}{f_{1} h_{2}} \pi_{t}^{e}+\frac{\left(h_{1}+l_{2}\right)\left(\beta j_{1}+j_{2}+f_{2}\right)+\beta f_{1} l_{1}}{\beta f_{1} h_{2}}\left[\frac{\kappa \alpha}{\lambda}\left(\pi_{t}-\pi^{T}\right)-y^{*}\right] \\
& +\frac{h_{1}+l_{2}}{f_{1} h_{2}}\left[\frac{f_{2}+j_{2}}{\beta} \varepsilon_{d t}-\varepsilon_{c t}\right]+\frac{1}{h_{2}}\left(\bar{b}_{t}-p_{t}\right)+\frac{1}{h_{2}}\left(\varepsilon_{m t}-\varepsilon_{l t}\right) .
\end{aligned}
$$

Equation (14) gives the optimal rule of discount rate. The target of the latter reacts to the expected inflation rate, the gap between current inflation and the inflation target, the natural rate of output and demand shocks similarly to the target of credit market interest rate except that the coefficients of reaction must also take account the imperfect transmission mechanism of monetary policy through the monetary and financial markets and shocks affecting the latter. Comparing with $i_{c t}^{T}$, the reactions of $i_{d t}^{T}$ to the expected inflation rate and demand shocks are amplified if $\frac{\left(h_{1}+l_{2}\right)\left(f_{2}+j_{2}\right)}{h_{2} f_{1}}>1$, and its reactions to the gap between the inflation rate and the inflation target and the natural rate of output are amplified if $\frac{\left(h_{1}+l_{2}\right)\left(f_{2}+\beta j_{1}+j_{2}\right)+\beta f_{1} l_{1}}{f_{1} h_{2}}>1$, and vice versa.

Proposition 2. To implement the inflation targeting regime, the target of the discount rate is adjusted to neutralize the effects of money demand and supply shocks and a variation in real currency $\left(\bar{b}_{t}-p_{t}\right)$ on the targets of money and credit market interest rates. ${ }^{7}$

Proof. It follows directly from the comparison of equations (12), (13) and (14).

Assume that the central bank implements the rule (14) and is not subject to the lower bound on the nominal interest rate so that the targets rates defined by (12), (13) and (14) are all realized, i.e. $i_{c t}=i_{c t}^{T}, i_{m t}=i_{m t}^{T}$ and $i_{d t}=i_{d t}^{T}$. Using equations (8)-(9) and (12)-(14), risk premiums are calculated as:

\footnotetext{
${ }^{7}$ It is to notice the term 'real currency' is used for simplicity. In effect, as we have defined before, $\bar{b}_{t}-p_{t}$ could also include a component which depends on the obligatory ratio set by the central bank.
} 


$$
\begin{aligned}
\rho_{c t}= & i_{c t}^{T}-i_{m t}^{T} \\
= & \frac{f_{1}-f_{2}-j_{2}}{f_{1}} \pi_{t}^{e}-\frac{\beta j_{1}+j_{2}-f_{1}+f_{2}}{\beta f_{1}}\left[\frac{\kappa \alpha}{\lambda}\left(\pi_{t}-\pi^{T}\right)-y^{*}\right]+\frac{f_{1}-f_{2}-j_{2}}{\beta f_{1}} \varepsilon_{d t}+\frac{1}{f_{1}} \varepsilon_{c t}, \\
\rho_{m t}= & i_{m t}^{T}-i_{d t}^{T} \\
= & -\frac{\left(f_{2}+j_{2}\right)\left(h_{1}-h_{2}+l_{2}\right)}{f_{1} h_{2}} \pi_{t}^{e}-\frac{\left(h_{1}-h_{2}+l_{2}\right)\left(f_{2}+\beta j_{1}+j_{2}\right)+l_{1} \beta f_{1}}{\beta f_{1} h_{2}}\left[\frac{\kappa \alpha}{\lambda}\left(\pi_{t}-\pi^{T}\right)-y^{*}\right] \\
& -\frac{1}{h_{2}}\left(\bar{b}_{t}-p_{t}\right)-\frac{h_{1}-h_{2}+l_{2}}{f_{1} h_{2}}\left(\frac{f_{2}+j_{2}}{\beta} \varepsilon_{d t}-\varepsilon_{c t}\right)-\frac{1}{h_{2}}\left(\varepsilon_{m t}-\varepsilon_{l t}\right) .
\end{aligned}
$$

In the absence of zero bound on the nominal interest rate, the risk premium between the credit market interest rate and the money market interest rate decreases with the expected inflation rate, the gap between the inflation rate and the inflation target and a positive aggregate demand shock, and it increases with the natural rate of output since $f_{1}-f_{2}-j_{2}<0$. It increases with a positive (negative) credit demand (supply) shock.

Given that $h_{1}-h_{2}+l_{2}>0$, the risk premium between the money market interest rate and the discount rate decreases with the expected inflation, the gap between the inflation rate and the inflation target and a positive aggregate demand shock, and increases with the natural rate of output and a positive credit demand shock. It decreases with $\bar{b}_{t}$ (the exogenous component of monetary base) and the money supply shock, and increases with the price level and the money demand shock. If we assume that the average values of the determinants of $\rho_{m t}$ are all constant (with $\left(\bar{b}_{t}-p_{t}\right)$ being considered as one term), then $\rho_{m t}$ can be assumed to follow a stochastic process with constant average and it is directly observed by market participants. ${ }^{8}$

If the central bank does not try to control the instantaneous risk premium between money market and discount rates at a strictly fixed level, it is not necessary to have the money supply totally endogenous. Observing the money market risk premium, the market participants can extract information useful for determining the expected inflation rate. If the central bank desires to influence inflation expectations, control can be exercised over a narrow monetary 
aggregate such as $\bar{b}_{t}$, and variations in this aggregate are then associated with variations in broader measures of money supply. Due to imperfection of the transmission mechanism of interest rate policy, the money supply becomes an independent instrument and the money market is not anymore redundant.

In normal situations, the central bank can attain the target of other interest rates by setting the discount rate, even though disturbances in financial and corporate sectors can create dislocation on financial markets and enlarge the difference between the discount rate and other interest rates. However, absorbing extreme negative disturbances in goods market may require a low target of credit market interest rate which may not be within the reach of the central bank due to simultaneous negative monetary and financial disturbances and the zero bound on the nominal discount rate. In this case, non-orthodox monetary policy, such as the quantitative easing policy, must be used to ease the tension on the money market or more audaciously the credit market through strengthening banks' balance sheet and/or buying private debts on the credit market by the central bank or Treasury.

Consequently, in the process of implementing the interest rate policy, the control of monetary aggregate may be very helpful particularly when the money and financial markets are perturbed and attaining the target of credit market interest rate may need excessively ample movements of the discount rate or even a negative discount rate. In the following, it is assumed that the central bank will always be able to attain the target of credit market interest rate by varying the discount rate within the range $i_{d t} \geq 0$. In the case of liquidity trap, i.e. the credit market interest rate is higher than its target level for $i_{d t}=0$, the central bank will practice a quantitative easing policy. More precisely, it will either discretionarily expand the money supply through an increase in $\bar{b}_{t}$, or buy assets on money and credit markets to reduce

\footnotetext{
${ }^{8}$ In the case where some terms, such as $y^{*}$, are not stationary, an appropriate answer of the real balances to the
} 
$\rho_{c t}$ and $\rho_{m t}$ in a way that $i_{c t}^{T}$ is attained.

\section{The dynamics of expected inflation}

As the expected inflation rate is determined before current inflation rate and output, its dynamic trajectory can be studied in a reduced dynamic system where $\pi_{t}$ and $y_{t}$ are substituted by their solution in terms of expected inflation, exogenous variables and shocks. Once the dynamic trajectory of $\pi_{t}^{e}$ is solved, one can determine these of $\pi_{t}$ and $y_{t}$. Assuming that the zero-bound on the nominal interest rate (if it exists) is avoided by quantitative easing policy and that the discount rate defined in (14) is implemented so that the credit market interest rate is equal to the target level defined by equation (12), equations (1)(2) and (12) enable us to solve inflation rate and output as function of expected inflation rate and inflation shock:

$$
\begin{aligned}
& \pi_{t}=\frac{\lambda}{\lambda+\kappa \alpha^{2}} \pi_{t}^{e}+\frac{\kappa \alpha^{2}}{\lambda+\kappa \alpha^{2}} \pi^{T}+\frac{\lambda}{\lambda+\kappa \alpha^{2}} \varepsilon_{\pi t}, \\
& y_{t}=y^{*}-\frac{\kappa \alpha}{\lambda+\kappa \alpha^{2}} \pi_{t}^{e}+\frac{\kappa \alpha}{\lambda+\kappa \alpha^{2}} \pi^{T}-\frac{\kappa \alpha}{\lambda+\kappa \alpha^{2}} \varepsilon_{\pi t} .
\end{aligned}
$$

Equations (17) and (18) are not final solutions for inflation rate and output gap respectively, which can only be obtained after having solved expected inflation rate. They show that, departing from an initial equilibrium where $\pi_{t}^{e}=\pi^{T}$, an increase in inflation expectations will positively impact current inflation and negatively current output.

The determination of inflation expectations in the inflation targeting literature only takes account of the information about the targeting rule, IS and Phillips curves, while the expected money growth rate as well as money and financial shocks (when they are persistent) have no 
impact on private inflation expectations. If shocks are always i.i.d., it follows from computing the mathematical expectations of equation (17) that $\pi^{e}=\pi^{T}$. The latter means that private agents will believe in the announced inflation target $\pi^{T}$ and the model becomes static. This is misleading for the central bank as well as for private agents when shocks are not perceived as random and transitory. For this reason, the revision of rational inflation expectations by market participants using more information is necessary. Since money and financial markets convey all information about the economy, it can serve as the co-ordination device for private agents in the formation of inflation expectations (Dai and Sidiropoulos, 2003). Private agents will use a whole set of information provided by money and financial markets to revise as fine as possible their expectations. Furthermore, the inclusion of monetary targeting in the monetary policy strategy implies that the money would have an important impact on the determination of the current price level and inflation, and thus future inflation.

In modern economies with developed financial markets, sophisticated financial instruments (such as inflation-indexed bonds, interest rate options, swaps and futures) are traded and implicitly convey market expectations about future inflation. In this simple model, in the absence of these complex financial instruments, private agents are assumed to directly learn from the information conveyed by the money market which is connected to other financial and real markets to determine the expected inflation rate underlying the movements of market interest rates (or prices of financial assets).

Denote $\mu_{t}^{e}=\dot{\bar{b}}_{t}^{e}$, i.e. the expected growth rate of the exogenous component of monetary base (called money growth rate thereafter for simplicity). Equations (16) and (17)-(18) allow deriving, for $\dot{\pi}^{T}=0$, the differential equation for expected inflation rate (Appendix B):

$$
\dot{\pi}_{t}^{e}=\Psi\left[\pi_{t}^{e}-\mu_{t}^{e}+\frac{\left(h_{1}-h_{2}+l_{2}\right)\left(f_{2}+\beta j_{1}+j_{2}\right)+l_{1} \beta f_{1}}{\beta f_{1}} \dot{y}^{* e}\right]+\Psi \Sigma_{t}^{e},
$$


with $\quad \Sigma_{t}^{e}=-\frac{\kappa \alpha\left[\left(h_{1}-h_{2}+l_{2}\right)\left(f_{2}+\beta j_{1}+j_{2}\right)+l_{1} \beta f_{1}\right]}{\beta f_{1}\left(\lambda+\kappa \alpha^{2}\right)} \dot{\varepsilon}_{\pi t}^{e}-\frac{h_{1}-h_{2}+l_{2}}{f_{1}}\left(\frac{f_{2}+j_{2}}{\beta} \dot{\varepsilon}_{d t}^{e}-\dot{\varepsilon}_{c t}^{e}\right)-\left(\dot{\varepsilon}_{m t}^{e}-\dot{\varepsilon}_{l t}^{e}\right)-h_{2} \dot{\rho}_{m t}^{e} \quad$ and $\Psi=\frac{\beta f_{1}\left(\lambda+\kappa \alpha^{2}\right)}{\left(h_{1}-h_{2}+l_{2}\right)\left[\beta\left(f_{2}+j_{2}\right)\left(\lambda+\kappa \alpha^{2}\right)+\kappa \alpha\left(f_{2}+\beta j_{1}+j_{2}\right)\right]+\kappa \alpha l_{1} \beta f_{1}}$. The term $\Sigma_{t}^{e}$ captures the expectations (or beliefs) about the persistence of different shocks. If all shocks are expected to be serially uncorrelated, it follows that $\Sigma_{t}^{e}=0$.

Equation (19) implies that the rate of change of the expected inflation rate is determined by the difference between the expected inflation rate and the expected money growth rate, the expected rate of change of the natural rate of output as well as the expected persistence of different shocks affecting decisions of private agents in their choice of consumption, production and acquisition of money and financial assets. Equation (19) can be easily solved for $\pi_{t}^{e}$ once $\mu_{t}^{e}, \dot{y}^{* e}$ and $\Sigma_{t}^{e}$ are specified (Buiter, 1984). In this study, the focus is put on the stability property of the adjustment process of $\pi_{t}^{e}$ and hence its solution is not given.

If shocks are all transitory white noises (serially non-correlated shocks, i.e., $\dot{\varepsilon}_{\pi t}^{e}=\dot{\varepsilon}_{d t}^{e}=\dot{\varepsilon}_{m t}^{e}=\dot{\varepsilon}_{l t}^{e}=\dot{\rho}_{m t}^{e}=\dot{\rho}_{c t}^{e}=0$ ), the solution $\pi^{e}=\pi^{T}$ is also the steady equilibrium solution of equation (19) which becomes $\dot{\pi}^{e}=\Psi\left(\pi^{e}-\pi^{T}\right)$ for $\mu_{t}^{e}=\pi_{t}^{T}+\frac{\left(h_{1}-h_{2}+l_{2}\right)\left(f_{2}+\beta j_{1}+j_{2}\right)+l_{1} \beta f_{1}}{\beta f_{1}} \dot{y}^{* e}$. Under the latter condition, at equilibrium, the economy will behave similarly to what happens under an inflation-targeting regime with perfect money and financial markets. However, equation (19) is a more realistic description of the revision mechanism of inflation expectations, since it also takes account of information about monetary and financial factors which are completely absent in equation (17), and hence the risk of instability due to them. Furthermore, it also allows examining the effects of market beliefs or persistent shocks (other than inflation shock) on inflation dynamics.

Equation (19) shows that the link between monetary policy and expected inflation is not obvious. Pure inflation-targeting regimes could fail (i.e. dynamically unstable) if a change in 
the discount rate does not induce appropriate variations in the market interest rates and money supply, hence leading to divergent inflation expectations. Adopting monetary aggregates as another policy instrument, the central bank can, through adjusting money growth (e.g. through adjusting the ratio of obligatory reserves or the currency) to create excess or shortage of liquidity, influence short-run inflation expectations in the way that they will not significantly deviate from the inflation target in the medium to long term.

During the last decade, even though inflation-targeting central banks' principal objectives (i.e. stabilization of inflation and output gap) are relatively well achieved, too much disequilibrium on the financial markets has been accumulated, translating into bubbles in real and financial asset prices. The fact that huge asset bubbles appear more frequently could be due to that central banks do not pay anymore attention to the increase in the quantity of money and credits. However, they pay great attention to these aggregates when the financial system and the real economy are facing the risk of collapsing. This asymmetrical behavior with regard to the quantity of money and credits could be at the origin of dramatic financial shocks with devastating effects on the real economy.

To avoid large self-inflicted financial shocks in the future without rejecting the recent important advances in the central banking such as inflation targeting which puts accent on central bank's independence and transparency, one solution is to combine inflation targeting with monetary targeting through the design of an optimal interest rate rule and an appropriate money growth rule, which are compatible with the dynamic stability of the economy.

By only setting the discount rate, in an aggressive manner or not, to indirectly affect the market interest rates, the central bank might have no credible instrument for anchoring inflation expectations besides the cheap talk about its firm intention to attain its inflation target. The real challenge appears whenever the economy is outside of equilibrium. When the inflation rate moves away from the announced target, verbal persuasion via the publication of 
the minutes, the monthly reports, the data, the procedures of decisions as well as the models used could be not enough to convince the public to adhere to the central bank's monetary policy decision. Temporary but persistent shocks could make further difficult the conduct of monetary policy through controlling the discount rate under the funds rate targeting procedure. Furthermore, rational speculative inflationary bubbles cannot be excluded in a dynamic framework.

Thus, in the absence of monetary targeting rule, inflation targeting might not be perfectly credible. ${ }^{9}$ In effect, to entirely believe that the inflation target is equivalent for private agents to believe that random shocks compensate each other and hence have no consequence in terms of average inflation. As their time horizons are different and far from infinite and the effects of shocks might not be mutually compensated in their respective time horizon, private agents might be incited to use an alternative method to form inflation expectations. The latter, to be adopted, has to reflect better their personal time horizon of decision during which the current inflation rate could be systematically different from the expected inflation rate due to permanent, persistent or even stochastic shocks. ${ }^{10}$ Therefore, private agents may find rational to lose some precious time to collect all information about the economy to form inflation expectations instead of only using the Phillips curve, IS curve and central bank's targeting rule, not to mention that the Phillips curve is also submitted to instability in the long-run and some important pitfalls. If this is the case, private agents could anticipate an inflation rate different from the announced inflation target. Thus, inflation targeting will not necessarily offer the nominal anchor for inflation expectations as assumed in the inflation-targeting literature.

\footnotetext{
9 The concept of imperfect credibility is used in the sense that private agents don't automatically and uniquely use the inflation target as nominal anchor and instead, they use information extracted from money and asset market equilibrium conditions to revise their inflation expectations.

10 The random nature of shocks does not exclude that the same kind of shocks occur repetitively and consecutively for several times.
} 
The central bank desires that private agents believe in its inflation target, even in the event of shocks inducing the realized inflation rate to deviate from the target. Considering that private sector scrutinizes money and financial markets to find out the market inflation expectations, the central bank concerned with ensuring that its credibility is not altered controls the growth rate of the narrow money supply at an average level and hence influences the liquidity available in the monetary and financial system in a way consistent with the inflation target. Therefore, the central bank might be able to more effectively anchor inflation expectations.

Introducing a monetary targeting rule does not mean that, to attain the inflation target, the central bank has to scrupulously fix the growth rate of a chosen monetary aggregate at a certain percentage because such aggregate could be subject to exogenous shocks or even disturbances due to speculative behaviors of financial operators.

If the monetary targeting rule is well specified, the inflation target of the central bank is always achieved when the effects of shocks disappear since the dynamic stability is embedded in the economy. Therefore, even if the expected and realized inflation rates can be temporarily different from the inflation target, their difference will decrease over time. Otherwise, an exogenous change in inflation expectations could lead the economy to deviate far from the equilibrium corresponding to the announced inflation and output objectives.

If the inflation target represents a nominal anchor of the economy, the control of money growth makes it more credible in the eyes of private agents and provides a kind of additional nominal anchor for inflation expectations.

The constant money growth rule has been considered as a failure in stabilizing inflation and inflation expectations. It is hence interesting to examine its capability of dynamic stabilization in this model and then compare it with alternative feedback money growth rules. 


\section{The dynamic behavior of the economy under Friedman's $k$-percent rule}

If the central bank desires a credible inflation-targeting policy, it could monitor the expected inflation in keeping an average long-term money growth rate consistent with its inflation target $\left(\pi^{T}\right)$. However, monetary targeting must not be considered as an independent strategy for achieving price stability by stabilizing inflation around a given inflation target since it faces, as shown by Svensson (1999), an unpleasant choice between being either inefficient and transparent or efficient and non-transparent.

Time derivation of equations (3) is at the base of pure monetary targeting. It implies that, in order to stabilize current and expected inflation rates around a constant steady state level, monetary authorities are constrained to set a money growth rate consistent with the inflation target, adjusted for variation in the natural rate of output. One example of monetary targeting rule consistent with the present model is:

$$
\mu_{t}^{e}=\bar{\mu}+\frac{\left(h_{1}-h_{2}+l_{2}\right)\left(f_{2}+\beta j_{1}+j_{2}\right)+l_{1} \beta f_{1}}{\beta f_{1}} \dot{y}^{*}, \quad \text { with } \bar{\mu}=\pi^{T} \text {. }
$$

This is a variant of Friedman's $k$-percent money growth rule. ${ }^{11}$ This kind of monetary targeting is a signal that the central bank is independent and fighting against price instability, and a means to define the role of monetary policymaker vis-à-vis other players in the macroeconomic policy game, and to structure the internal monetary policy debate (von Hagen, 1999).

Taking account of equation (20), equation (19) becomes:

$$
\dot{\pi}_{t}^{e}=\Psi\left(\pi_{t}^{e}-\bar{\mu}\right)+\Psi \Sigma_{t}^{e}
$$

\footnotetext{
11 This is consistent with the practice of Bundesbank. Each year, Bundesbank sets its money-growth target equal to the sum of an inflation target, a forecast of the growth of potential output, and an estimated trend in velocity (Svensson, 1999).
} 
As in Buiter and Panigirtzoglou (2003), the inflation rate and hence the expected inflation rate are treated as predetermined. In effect, it is quite reasonable to admit that $\pi^{e}$ is a predetermined variable in a low inflation environment, where the adjustments of prices and thus of current and expected inflation rates are quite slow due to different mechanisms causing nominal rigidities in the short-run (menu costs, partial adjustments, overlapping contracts etc.). As the expected inflation rate cannot instantly jump to its equilibrium value, the system is unstable.

The dynamic behavior of the economy described by equation (21) can be summarized in the following proposition.

Proposition 3. Under the discount rate rule (14) and Friedman's k-percent money growth rule (20), the expected and realized inflation rates, real output and real money stock will follow an unstable dynamic process of adjustment.

Proof: The eigenvalue of the dynamic equation (21) equals $\Psi>0$.

The expected inflation rate is indeterminate under Friedman's $k$-percent rule in the sense that it will be on a divergent trajectory whenever the system is hit by a shock (or even a perception error). If the expected inflation rate diverges from its equilibrium value following a shock, equations (17)-(18) imply that the realized inflation and output would follow similar divergent trajectories. It follows that the real money demand is also unstable. This observation is interesting since instability in money demand is notably observed when, in practice, central banks use interest rate policy more intensely while keeping simple monetary targeting rule.

Hence, the monetary targeting rule specified in equation (20) might not be considered as a warrant against major deviations of current and expected inflation rates from the inflation target and thus might not reinforce the private belief about the chance of success of monetary authorities in implementing an interest rate policy consistent with the inflation target. 
Under an alternative assumption according to which the expected inflation rate, as a nonpredetermined variable, can freely jump to attain its equilibrium value, the equilibrium will be saddle-point stable. ${ }^{12}$ However, when the system is perturbed by shocks, the jumping expected inflation rate can miss the target and is therefore submitted to the risk of following a nonconverging trajectory, leading to speculative inflation or deflation.

Therefore, whatever is the nature (predetermined or non-predetermined) of expected inflation rate, it is better to appropriately adjust the money growth rate through an alternative rule to ensure that the dynamic system has a stable equilibrium.

It is easy to understand why macroeconomic instability could arise as a result of implementing an optimal discount rate rule combined with a rigid money growth rule. Departing from an initial equilibrium, answering to an increase in inflation expectations due to a shock, the central bank raises the discount rate, which induces an increase in money and credit market interest rates, leading hence to a decrease in output (due to a higher credit market interest rate) as well as a decrease in real money demand (due to a higher money market interest rate and lower revenue). For given money growth rate determined by the central bank according to (20), a higher money market interest rate implies a supplementary money supply growth due to money-multiplier effects according to equation (4). With a reduced real money demand, the equilibrium condition of money market implies a higher future inflation rate that economic agents could easily anticipate if they attentively observe this market. Workers could ask higher nominal wages to compensate for the loss of purchasing power due to a higher future inflation. This will effectively generate further inflationary pressures.

In effect, emerging market economies (i.e., Latin American countries during the 1980s) and transition economies (i.e., Eastern European countries in 1990s) provide numerous

\footnotetext{
12 The equilibrium is saddle-point stable if the number of unstable eigenvalues is inferior or equal to the number of non-predetermined variables (See Buiter, 1984).
} 
examples where a sharp increase in nominal interest rate did not allow reducing expected and hence realized inflation rates.

\section{Feedback monetary targeting rules}

The instability result of $k$-percent money growth rule under inflation-targeting regime is due to the fact that the money growth rate determined by the central bank is given while the interest rate policy is tightening or relaxing to answer to different shocks. The solution to this problem is to fine-tune the monetary targeting rule so that it reacts to changing economic and financial conditions in harmony with optimal discount rate rule.

Two feedback money growth rules will be considered in the following. A component destined to counterbalance the effects of observable shocks on inflation expectations can also be integrated in these rules. They can be implemented thanks to nonprice rationing of access to the central liquidity by the commercial banks, adjustment of the ratio of obligatory reserves and/or control of the emission of currency. To imbed the dynamic stability in the economic system, it is important to choose the appropriate value of the parameter characterizing the feedback component of these rules.

\subsection{Money growth varying with the rate of change in output}

The first feedback money growth rule remedying the dynamic instability due to the Friedman's $k$-percent rule (20) is specified to react to the variation of output:

$$
\mu_{t}=\bar{\mu}+\left[\frac{\left(h_{1}-h_{2}+l_{2}\right)\left(f_{2}+\beta j_{1}+j_{2}\right)+l_{1} \beta f_{1}}{\beta f_{1}}-\eta\right] \dot{y}^{*}+\eta \dot{y}_{t}, \quad \text { with } \bar{\mu}=\pi^{T} .
$$

This rule is similar to the one considered by Taylor (1985), McCallum (1988a, b), Judd and Motley (1991), Hess, Small and Brayton (1993), and Feldstein and Stock (1994). The monetary targeting rule (22) implies that the central bank accommodates the variation of 
output over the current period when determining the current money growth rate. Time derivation of equation (18) gives $\dot{y}_{t}=\dot{y}^{*}-\frac{\kappa \alpha}{\lambda+\kappa \alpha^{2}}\left(\dot{\pi}_{t}^{e}+\dot{\varepsilon}_{\pi t}^{e}\right)$. Substituting the latter into equation (22) and computing the mathematical expectations of the resulting equation lead to $\mu_{t}^{e}=\bar{\mu}+\frac{\left(h_{1}-h_{2}+l_{2}\right)\left(f_{2}+\beta j_{1}+j_{2}\right)+l_{1} \beta f_{1}}{\beta f_{1}} \dot{y}^{*}-\eta \frac{\kappa \alpha}{\lambda+\kappa \alpha^{2}}\left(\dot{\pi}_{t}^{e}+\dot{\varepsilon}_{\pi t}^{e}\right)$. Substituting then $\mu_{t}^{e}$ by its solution in equation (19) gives the dynamic equation for expected inflation rate:

$$
\dot{\pi}_{t}^{e}=\frac{\left(\lambda+\kappa \alpha^{2}\right) \Psi}{\lambda+\kappa \alpha^{2}-\kappa \alpha \eta \Psi}\left(\pi_{t}^{e}-\bar{\mu}+\Sigma_{t}^{e}+\frac{\eta \kappa \alpha}{\lambda+\kappa \alpha^{2}} \dot{\varepsilon}_{\pi t}^{e}\right) .
$$

Proposition 4a. The dynamic equation (23), which is established under the discount rate rule (14) and the money growth rule (22), has a stable equilibrium solution if $\eta>\frac{\lambda+\kappa \alpha^{2}}{\kappa \alpha \Psi}$.

Proof. To demonstrate Proposition 4a, one considers the eigenvalue of the dynamic equation (23), i.e. $\frac{\Psi\left(\lambda+\kappa \alpha^{2}\right)}{\lambda+\kappa \alpha^{2}-\Psi \kappa \alpha \eta}$. It is negative if $\lambda+\kappa \alpha^{2}-\Psi \kappa \alpha \eta<0$, i.e. $\frac{\lambda+\kappa \alpha^{2}}{\kappa \alpha \Psi}<\eta$. Under this condition, the expected inflation rate is determinate and converges to its equilibrium value following any shock.

An increase in the expected inflation rate which is initially at its equilibrium level will induce higher interest rates, hence lower output and money demand but higher money supply and inflation. To avoid that the expected inflation rate deviates further from its equilibrium level, the monetary targeting rule (22), which responds to the decrease in output by sufficiently reducing the money growth rate, allows equilibrating the money market at lower and lower expected inflation rates. Consequently, escalating increases in nominal discount rate are unnecessary to contain higher expected inflation rates in the future. 
Proposition $4 b$. The threshold value of $\eta$, i.e. $\min \eta \equiv \frac{\lambda+\kappa \alpha^{2}}{\kappa \alpha \Psi}$, over which $\eta$ is compatible with stable equilibrium, decreases with $\kappa, \beta, f_{1}$ and $h_{2}$, and increases with $\lambda, l_{1}, l_{2}, j_{1}$, $j_{2}, f_{2}$ and $h_{1}$. It increases with $\alpha$ if $\frac{\lambda}{\kappa}<\alpha^{2}$.

Proof. See Appendix C.

The minimal value of $\eta, \min \eta$, compatible with stable equilibrium increases with the weight assigned to output stabilization $\lambda$ and decreases if the central bank worries more about the realization of the inflation target $\kappa$.

It also varies with other parameters reflecting the economic and financial characteristics of the economy. Financial developments have considerable importance when the central bank designs a money growth rule. Higher interest-elasticity of aggregate demand (greater $\beta$ ), higher elasticity of credit and money supply relative to the refinancing conditions (greater $f_{1}$ and greater $h_{2}$ ), more efficient transaction and payment system (smaller $l_{1}$ ), smaller semiinterest elasticity of money demand (smaller $l_{2}$ ), lower revenue-elasticity of credit demand (smaller $j_{1}$ ), and lower interest-elasticity of credit supply (smaller $f_{2}$ ) allow the central bank to vary less strongly money growth (smaller $\min \eta$ ) in response to the rate of change in output without generating macro-economic instability. A less flexible labor market (smaller $\alpha$, but under the condition $\frac{\lambda}{\kappa}<\alpha^{2}$ ) has similar effect on $\min \eta$. It is to notice that financial innovations increasing the semi-interest elasticity of money demand (greater substitution between money and financial assets) require the central bank to keep the money supply more reactive to the variation in output.

\subsection{Money growth reacting to the variation of inflation rate}


The second feedback monetary targeting rule negatively links the money growth rate to the variation of inflation:

$$
\mu_{t}=\bar{\mu}+\frac{\left(h_{1}-h_{2}+l_{2}\right)\left(f_{2}+\beta j_{1}+j_{2}\right)+l_{1} \beta f_{1}}{\beta f_{1}} \dot{y}^{*}-\varphi \dot{\pi}_{t}, \quad \text { with } \bar{\mu}=\pi^{T}
$$

Substituting $\dot{\pi}_{t}$ by $\dot{\pi}_{t}^{e}$ in equation (24) will only slightly modify the results. Introducing $\dot{\pi}^{e}$ has even some advantages if indexed and non-indexed bonds are simultaneously quoted on financial markets since, in this case, the expected inflation rate is directly derived from observing the spread between interest rates, while the realised inflation rate must be calculated with data which may not be quickly available. Using equation (17) to obtain $\dot{\pi}_{t}=\frac{\lambda}{\lambda+\kappa \alpha^{2}}\left(\dot{\pi}_{t}^{e}+\dot{\varepsilon}_{\pi t}\right)$ and substituting it into equation (24) lead to:

$$
\mu_{t}=\bar{\mu}+\frac{\left(h_{1}-h_{2}+l_{2}\right)\left(f_{2}+\beta j_{1}+j_{2}\right)+l_{1} \beta f_{1}}{\beta f_{1}} \dot{y}^{*}-\frac{\varphi \lambda}{\lambda+\kappa \alpha^{2}}\left(\dot{\pi}_{t}^{e}+\dot{\varepsilon}_{\pi t}\right), \quad \text { with } \bar{\mu}=\pi^{T} .
$$

The mathematical expectations of equation (25) allows determining $\mu_{t}^{e}$. Inserting it into equation (19) yields:

$$
\dot{\pi}_{t}^{e}=\frac{\left(\lambda+\kappa \alpha^{2}\right) \Psi}{\lambda+\kappa \alpha^{2}-\varphi \lambda \Psi}\left[\pi_{t}^{e}-\bar{\mu}+\frac{\varphi \lambda}{\lambda+\kappa \alpha^{2}} \dot{\varepsilon}_{\pi t}^{e}+\Sigma_{t}^{e}\right]
$$

Proposition 5a. Under the discount rate rule (14) and the money growth rule (24), the equilibrium solution of equation (26) is dynamically stable if $\varphi>\frac{\lambda+\kappa \alpha^{2}}{\lambda \Psi}$.

Proof. To demonstrate Proposition 5a, it is sufficient to show that the eigenvalue of dynamic equation (26) is negative when $\lambda+\kappa \alpha^{2}-\varphi \lambda \Psi<0$ or equivalently $\frac{\lambda+\kappa \alpha^{2}}{\lambda \Psi}<\varphi$. Therefore, the dynamic system has a stable equilibrium.

In the event of an increase in expected inflation rate due to a shock, the central bank raises the discount rate to increase money and credit market interest rates. The resulting decrease in money demand (due to a higher money market interest rate and lower revenue) and increase in 
money supply (due to a higher money market interest rate) imply higher inflationary pressures. The monetary targeting rule (24) with $\varphi>\frac{\lambda+\kappa \alpha^{2}}{\Psi \lambda}$ allows sufficiently reducing the money growth rate in response to a higher inflation rate, hence dampening the increase in expected and realized inflation rates, without resorting to an excessive response in the discount rate.

Proposition 5b. The threshold value of $\varphi$, i.e. $\min \varphi \equiv \frac{\lambda+\kappa \alpha^{2}}{\lambda \Psi}$, over which $\varphi$ is compatible with stable equilibrium, decreases with $\lambda, \beta, f_{1}$ and $h_{2}$, and increases with $\kappa, l_{1}, l_{2}, j_{1}, j_{2}$, $f_{2}, h_{1}$ and $\alpha$.

Proof. See Appendix D.

The threshold value of $\varphi$, i.e. $\min \varphi$, diminishes with the weight assigned to output stabilization (greater $\lambda$ ) and increases with the weight assigned to inflation stabilization (greater $\kappa$ ), contrary to the threshold value of $\eta$, i.e. $\min \eta$. It varies also with structural parameters similarly to $\min \eta$ associated with the money growth rule (22), except that the relation between the $\min \varphi$ and $\alpha$ is not anymore submitted to a bound imposed on $\frac{\lambda}{\kappa}$.

The results summarized in Propositions 4a and 5a are compatible with the view of the modern quantitative theory of money. According to the latter, whenever there is an inflationary pressure, the money supply must be tightened to limit the rise of prices. The implications of these propositions are also compatible with the inflation-targeting framework in the sense that the optimal discount rate rule is designed to minimize the loss function of the central bank subject to the Phillips and IS curves, even though the equilibrium conditions relating different interest rates also have to be taken into account. However, when money and financial markets are imperfect in transmitting the effects of discount rate decisions to the economy, the design of a dynamically stabilizing 'two-pillar' strategy, i.e. the combination of inflation targeting and monetary targeting, implies that the money supply policy must not be 
rigidified as a $k$-percent rule according to Proposition 3. It is shown that the money supply, which is partially endogenous and imperfectly elastic due to nonprice rationing of access to the central and inside liquidity, must be regulated by adopting well-designed feedback money growth rules.

Most importantly, the principal findings of this study call into question some clichés of the modern quantitative theory of money as well as these of the standard stochastic inflation targeting framework. At one hand, under $k$-percent money growth rule, the resulting excess of liquidity due to diminishing real money demand for transaction and speculation is translated into vicious circle of increasing expected inflation rate, increasing nominal and real interest rates and diminishing real money demand. To avoid that, money growth rules given in (22) and (24) or their linear combination suggest to sufficiently diminish the liquidity in the economy when current inflation rate varies positively and current output varies negatively. On the other hand, in order to curb an increase in the inflation rate, inflation targeting implies an increase in the nominal interest rate to sufficiently raise the real interest rate. But this is not sufficient to ensure the dynamic stability of the economy when the central bank, under the funds rate targeting procedure, has only indirect control of market interest rates and private agents use all information, including that extracted from money and financial markets, to form inflation expectations.

\section{Conclusion}

In this paper, using a model which incorporates imperfect money, credit and reserves markets, we reconsider the monetary policy strategy of an inflation-targeting central bank operating under the funds rate targeting procedure. It is argued that, when money and financial markets imperfectly transmit the effects of interest rate policy to the economy, the cheap talk of central 
bankers may not be sufficient to ensure the announced inflation target as credible nominal anchor of private inflation expectations and inflation-targeting central banks have good reasons to use monetary targeting together with inflation targeting. Using as communication and anchoring device, well-conceived monetary targeting with a commitment to a long-run money growth rate consistent with the inflation target, as part of a hybrid inflation-targeting regime similar to the ECB's two-pillar monetary policy strategy, could effectively reinforce the credibility of the central bank and the role of the inflation target as strong and credible nominal anchor for inflation expectations.

It is shown that the narrow monetary aggregate, i.e. a component of monetary base, should be regulated with a rule but not in the way conceived by Milton Friedman. The inflationtargeting regime associated with Friedman's simple $k$-percent money growth rule can generate macro-economic instability. In effect, to ensure the macroeconomic stability, the money growth rate must be flexibly adjusted to answer directly or/and indirectly to shocks affecting inflation adjustment, aggregate spending, and money and financial markets. It is important that feedback money growth rules are designed to sufficiently diminish the liquidity in the economy when current inflation rate varies positively or/and current output varies negatively. Moreover, the design of these rules implies a careful account of the structural parameters of the economy as well as the preferences of the central bank.

\section{Appendix A: The money supply under the funds rate targeting procedure}

The monetary base $M B_{t}$ is decomposed as the sum of the total reserve $T R_{t}$ and currency $C_{t}$, the latter is assumed to be exogenously fixed by the central bank. Expressing this relationship in log terms yields:

$$
b_{t} \equiv \log M B_{t}=\frac{T R^{*}}{M B^{*}} \log T R_{t}+\frac{C^{*}}{M B^{*}} \log C_{t} \equiv \psi \chi_{t}+(1-\psi) c_{t}
$$


where $\chi_{t} \equiv \log T R_{t}, c_{t} \equiv \log C_{t}, \psi \equiv \frac{T R^{*}}{M B^{*}}$, and the superscript asterisk designs the steady state.

To establish the link between the $b_{t}$ and the discount rate, we use a simplified description of the reserve market. The central bank is assumed to use a funds rate targeting procedure, under which it controls the discount rate $i_{d t}$ and conducts open market operations to affect the supply of reserves in the banking system to target the funds rate, $i_{f t}$, the interest rate banks in need of reserves pay to borrow from banks with surplus reserves. Thus, total reserves and hence the monetary base $b_{t}$ will depend on $i_{d t}$.

Reserve demand arises primarily from the requirement that banks hold reserves equal to a specified fraction of their deposit liability and is assumed to be a negative function of $i_{d t}$. Other factors such as aggregate income and prices are simply treated as part of the error term, $v_{t}^{d}$, i.e. a disturbance of reserve demand. The function of total reserve demand is:

$$
\chi_{t}^{d} \equiv \log T R_{t}^{d}=-\phi i_{f t}+v_{t}^{d} .
$$

The total supply of reserves held by banking system can be expressed as the sum of the reserves that banks have borrowed from the central bank $\left(B R_{t}\right)$ plus nonborrowed reserves $\left(N B R_{t}\right)$, i.e. $T R_{t}^{S}=B R_{t}+N B R_{t}$. Rewriting this relation in log terms gives

$$
\chi_{t}^{s} \equiv \log T R_{t}^{s} \approx \frac{B R^{*}}{T R^{*}} \log B R_{t}+\frac{N B R^{*}}{T R^{*}} \log N B R_{t}=\gamma \chi_{t}^{b}+(1-\gamma) \chi_{t}^{n b}
$$

where $\gamma \equiv \frac{B R^{*}}{T R^{*}}, \chi_{t}^{b} \equiv \log B R_{t}$ and $\chi_{t}^{n b} \equiv \log N B R_{t}$.

The reserve market is in equilibrium whenever we have

$$
\chi_{t}^{d}=\chi_{t}^{s} .
$$


We postulate, similarly to Walsh (2003), a simple reserve borrowing function: ${ }^{13}$

$$
\chi_{t}^{b}=\zeta\left(i_{f t}-i_{d t}\right)+v_{t}^{b}, \quad \zeta>0
$$

The parameter $\zeta$ specifies how a variation in $i_{f t}$ affects reserve borrowings. It depends on how such a variation affects expectations of future funds rate levels which are not modelled here. Non-price rationing of access to the central liquidity implies that $i_{f t} \neq i_{d t}$. The shock $v_{t}^{b}$ stands for other factors which affect reserve borrowings.

Under the funds rate targeting procedure, the effects on $i_{f t}$ of shocks affecting the reserve demand and the borrowed reserves are entirely compensated by the central bank. Hence, the funds rate is determined by the discount rate. Nevertheless, the funds rate targeting is imperfect and is subject to a monetary policy shock $v_{t}^{s}$. The nonborrowed reserves are given by: 14

$$
\chi_{t}^{n b}=\frac{1}{1-\gamma} v_{t}^{d}-\frac{\gamma}{1-\gamma} v_{t}^{b}+v_{t}^{s}
$$

Using equations (A.2)-(A.3) and (A.5)-(A.6), the equilibrium condition on the reserve market (A.4) is rewritten as:

$$
-\phi i_{f t}=\gamma \zeta\left(i_{f t}-i_{d t}\right)+(1-\gamma) v_{t}^{s}
$$

Solving equations (A.2) and (A.7) for $i_{t}^{f}$ and $\chi_{t}$ in terms of $i_{t}^{d}$ and shocks gives:

$$
\begin{aligned}
& i_{f t}=\frac{\zeta \gamma}{\phi+\zeta \gamma} i_{d t}-\frac{1-\gamma}{\phi+\zeta \gamma} v_{t}^{s}, \\
& \chi_{t}=-\frac{\phi \zeta \gamma}{\phi+\zeta \gamma} i_{d t}+\frac{\phi(1-\gamma)}{\phi+\zeta \gamma} v_{t}^{s}+v_{t}^{d} .
\end{aligned}
$$

\footnotetext{
13 The specification of functions $B R_{t}$ and $N B R_{t}$ follows Walsh (2003). They are rewritten in logs terms here. In more elaborated reserve market model, the total supply of reserves could also depend on future interest rates (Walsh, 1982; Goodfriends, 1983).

14 For the implications of other operating procedures and a brief history of operating procedures used by the Fed and some other central banks, see Walsh (2003, pages 451-71).
} 
Substituting $\chi_{t}$ given by equation (A.9) into equation (A.1) and assuming that $c_{t}=\bar{c}$ (i.e. the amount of currency is given at period $t$ ), the monetary base is rewritten as

$$
b_{t}=-\frac{\phi \zeta \gamma \psi}{\phi+\zeta \gamma} i_{d t}+\frac{\phi \psi(1-\gamma)}{\phi+\zeta \gamma} v_{t}^{s}+\psi v_{t}^{d}+(1-\psi) \bar{c}
$$

Using equations (A.10) and (4), the money supply is written as:

$$
m_{t}=-\frac{\phi \zeta \gamma \psi}{\phi+\zeta \gamma} i_{d t}+\frac{\phi \psi(1-\gamma)}{\phi+\zeta \gamma} v_{t}^{s}+\psi v_{t}^{d}+(1-\psi) \bar{c}+h_{1} i_{m t}+\omega_{t}
$$

Define $\bar{b}_{t} \equiv(1-\psi) \bar{c}, h_{2} \equiv \frac{\phi \zeta \gamma \psi}{\phi+\zeta \gamma}$ and $\varepsilon_{m t} \equiv \frac{\phi \psi(1-\gamma)}{\phi+\zeta \gamma} v_{t}^{s}+\psi v_{t}^{d}+\omega_{t}$. This leads to equation (5).

\section{Appendix B: Dynamics of the expected inflation rate $\left(\dot{\pi}^{e}\right)$}

At the end of a period, private agents revise their inflation expectations for the future using all information about the economy, including that extracted from the equilibrium conditions on the money and financial markets. Assume that $\dot{\pi}^{T}=0$ and denote $\dot{\bar{b}}_{t} \equiv \mu_{t}$. Time derivation of equations (16) and (17) and leads to:

$$
\begin{aligned}
\dot{\rho}_{m t}= & -\frac{\left(f_{2}+j_{2}\right)\left(h_{1}-h_{2}+l_{2}\right)}{f_{1} h_{2}} \dot{\pi}_{t}^{e}-\frac{\left(h_{1}-h_{2}+l_{2}\right)\left(f_{2}+\beta j_{1}+j_{2}\right)+l_{1} \beta f_{1}}{\beta f_{1} h_{2}}\left[\frac{\kappa \alpha}{\lambda+\kappa \alpha^{2}} \dot{\pi}_{t}-\dot{y}^{*}\right] \\
& -\frac{1}{h_{2}}\left(\mu_{t}-\pi_{t}\right)-\frac{h_{1}-h_{2}+l_{2}}{f_{1} h_{2}}\left(\frac{f_{2}+j_{2}}{\beta} \dot{\varepsilon}_{d t}-\dot{\varepsilon}_{c t}\right)-\frac{1}{h_{2}}\left(\dot{\varepsilon}_{m t}-\dot{\varepsilon}_{l t}\right) . \\
\dot{\pi}_{t}= & \frac{\lambda}{\lambda+\kappa \alpha^{2}} \dot{\pi}_{t}^{e}+\frac{\lambda}{\lambda+\kappa \alpha^{2}} \dot{\varepsilon}_{\pi t},
\end{aligned}
$$

Substituting $\dot{\pi}_{t}$ given by equations (B.2) into (B.1) yields:

$$
\begin{aligned}
\dot{\rho}_{m t}= & -\frac{\left(f_{2}+j_{2}\right)\left(h_{1}-h_{2}+l_{2}\right)}{f_{1} h_{2}} \dot{\pi}_{t}^{e}-\frac{\left(h_{1}-h_{2}+l_{2}\right)\left(f_{2}+\beta j_{1}+j_{2}\right)+l_{1} \beta f_{1}}{\beta f_{1} h_{2}}\left[\frac{\kappa \alpha}{\lambda+\kappa \alpha^{2}}\left(\dot{\pi}_{t}^{e}+\dot{\varepsilon}_{\pi t}\right)-\dot{y}^{*}\right] \\
& -\frac{1}{h_{2}}\left(\mu_{t}-\pi_{t}\right)-\frac{h_{1}-h_{2}+l_{2}}{f_{1} h_{2}}\left(\frac{f_{2}+j_{2}}{\beta} \dot{\varepsilon}_{d t}-\dot{\varepsilon}_{c t}\right)-\frac{1}{h_{2}}\left(\dot{\varepsilon}_{m t}-\dot{\varepsilon}_{l t}\right) .
\end{aligned}
$$

The mathematical expectations of equation (B.3) imply:

$$
\begin{aligned}
\dot{\rho}_{m t}^{e}= & -\frac{\left(f_{2}+j_{2}\right)\left(h_{1}-h_{2}+l_{2}\right)}{f_{1} h_{2}} \dot{\pi}_{t}^{e}-\frac{\left(h_{1}-h_{2}+l_{2}\right)\left(f_{2}+\beta j_{1}+j_{2}\right)+l_{1} \beta f_{1}}{\beta f_{1} h_{2}}\left[\frac{\kappa \alpha}{\lambda+\kappa \alpha^{2}}\left(\dot{\pi}_{t}^{e}+\dot{\varepsilon}_{\pi t}^{e}\right)-\dot{y}^{* e}\right] \\
& -\frac{1}{h_{2}}\left(\mu_{t}^{e}-\pi_{t}^{e}\right)-\frac{h_{1}-h_{2}+l_{2}}{f_{1} h_{2}}\left(\frac{f_{2}+j_{2}}{\beta} \dot{\varepsilon}_{d t}^{e}-\dot{\varepsilon}_{c t}^{e}\right)-\frac{1}{h_{2}}\left(\dot{\varepsilon}_{m t}^{e}-\dot{\varepsilon}_{l t}^{e}\right) .
\end{aligned}
$$


Rearranging the terms in (B.4) yields the dynamic equation for expected inflation rate.

\section{Appendix C: Proof of Proposition 4b}

Using the definition of $\Psi$, we write $\min \eta \equiv \frac{\left(h_{1}-h_{2}+l_{2}\right)\left[\beta\left(f_{2}+j_{2}\right)\left(\lambda+\kappa \alpha^{2}\right)+\kappa \alpha\left(f_{2}+\beta j_{1}+j_{2}\right)\right]+\kappa \alpha l_{1} \beta f_{1}}{\kappa \alpha \beta f_{1}}$. To show Proposition 4b, we derive $\min \eta$ with respect to different parameters as follows:

$$
\begin{aligned}
& \frac{\partial \min \eta}{\partial \lambda}=\frac{\left(f_{2}+j_{2}\right)\left(h_{1}-h_{2}+l_{2}\right)}{\kappa \alpha f_{1}}>0 ; \frac{\partial \min \eta}{\partial \kappa}=\frac{-\lambda\left(f_{2}+j_{2}\right)\left(h_{1}-h_{2}+l_{2}\right)}{\kappa^{2} \alpha f_{1}}<0 ; \\
& \frac{\partial \min \eta}{\partial \alpha}=\frac{\beta\left(f_{2}+j_{2}\right)\left(h_{1}-h_{2}+l_{2}\right)\left(\kappa \alpha^{2}-\lambda\right)}{\kappa \alpha \beta f_{1}}>0, \text { if } \frac{\lambda}{\kappa}<\alpha^{2} ; \\
& \frac{\partial \min \eta}{\partial \beta}=\frac{-\left(h_{1}-h_{2}+l_{2}\right)\left(f_{2}+j_{2}\right)}{\beta^{2} f_{1}}<0 ; \\
& \frac{\partial \min \eta}{\partial l_{1}}=1 ; \frac{\partial \min \eta}{\partial l_{2}}=\frac{\beta\left(f_{2}+j_{2}\right)\left(\lambda+\kappa \alpha^{2}\right)+\kappa \alpha\left(f_{2}+\beta j_{1}+j_{2}\right)}{\kappa \alpha \beta f_{1}}>0 ; \\
& \frac{\partial \min \eta}{\partial f_{1}}=\frac{-\left(h_{1}-h_{2}+l_{2}\right)\left[\beta\left(f_{2}+j_{2}\right)\left(\lambda+\kappa \alpha^{2}\right)+\kappa \alpha\left(f_{2}+\beta j_{1}+j_{2}\right)\right]}{\kappa \alpha \beta f_{1}^{2}}<0 ; \\
& \frac{\partial \min \eta}{\partial f_{2}}=\frac{\left(h_{1}-h_{2}+l_{2}\right)\left[\beta\left(\lambda+\kappa \alpha^{2}\right)+\kappa \alpha\right]}{\kappa \alpha \beta f_{1}}>0 ; \\
& \frac{\partial \min \eta}{\partial j_{1}}=\frac{1}{f_{1}}>0 ; \frac{\partial \min \eta}{\partial j_{2}}=\frac{\left(h_{1}-h_{2}+l_{2}\right)\left[\beta\left(\lambda+\kappa \alpha^{2}\right)+\kappa \alpha\right]}{\kappa \alpha \beta f_{1}}>0 \\
& \frac{\partial \min \eta}{\partial h_{1}}=\frac{\beta\left(f_{2}+j_{2}\right)\left(\lambda+\kappa \alpha^{2}\right)+\kappa \alpha\left(f_{2}+\beta j_{1}+j_{2}\right)}{\kappa \alpha \beta f_{1}}>0 ; \\
& \frac{\partial \min \eta}{\kappa \alpha \beta f_{1}}=\frac{-\left[\beta\left(f_{2}+j_{2}\right)\left(\lambda+\kappa \alpha^{2}\right)+\kappa \alpha\left(f_{2}+\beta j_{1}+j_{2}\right)\right]}{\square}<0 .
\end{aligned}
$$

\section{Appendix D: Proof of Proposition 5b}


To show Proposition 5b, we derive $\min \varphi \equiv \frac{\left(h_{1}-h_{2}+l_{2}\right)\left[\beta\left(f_{2}+j_{2}\right)\left(\lambda+\kappa \alpha^{2}\right)+\kappa \alpha\left(f_{2}+\beta j_{1}+j_{2}\right)\right]+\kappa \alpha l_{1} \beta f_{1}}{\beta f_{1} \lambda}$ with respect to different parameters. Comparing $\min \eta \equiv \frac{\lambda+\kappa \alpha^{2}}{\kappa \alpha \Psi}$ and $\min \varphi \equiv \frac{\lambda+\kappa \alpha^{2}}{\lambda \Psi}$, it follows that $\min \varphi=\frac{\kappa \alpha}{\lambda} \min \eta$. Thus, the derivatives of $\min \varphi$ with respect to $\beta, l_{1}, l_{2}, h_{1}, h_{2}, j_{1}, j_{2}, f_{1}$ and $f_{2}$ can be easily obtained from multiplying by $\frac{\kappa \alpha}{\lambda}$ the corresponding ones of $\min \eta$. It is hence straightforward to obtain their sign. Thus, we only give the following derivates:

$$
\begin{aligned}
& \frac{\partial \min \varphi}{\partial \lambda}=-\frac{\left(h_{1}-h_{2}+l_{2}\right)\left[\left(f_{2}+j_{2}\right)(1+\alpha \beta) \kappa \alpha+\kappa \alpha \beta j_{1}\right]+\kappa \alpha l_{1} \beta f_{1}}{\beta f_{1} \lambda^{2}}<0 ; \\
& \frac{\partial \min \varphi}{\partial \kappa}=\frac{\alpha\left(h_{1}-h_{2}+l_{2}\right)\left[\left(f_{2}+j_{2}\right)(1+\alpha \beta)+\beta j_{1}\right]+\alpha l_{1} \beta f_{1}}{\beta f_{1} \lambda}>0 ; \\
& \frac{\partial \min \varphi}{\partial \alpha}=\frac{\kappa\left(h_{1}-h_{2}+l_{2}\right)\left[\left(f_{2}+j_{2}\right)(1+2 \alpha \beta)+\beta j_{1}\right]+\kappa l_{1} \beta f_{1}}{\beta f_{1} \lambda}>0 .
\end{aligned}
$$

\section{References:}

Adam, Klaus \& Roberto Billi (2007), "Discretionary Monetary Policy and the Zero Lower Bound on Nominal Interest Rates," Journal of Monetary Economics 54, 728-752.

Assenmacher-Wesche, Katrin \& Stefan Gerlach (2007), "Understanding the Link between Money Growth and Inflation in the Euro Area," in: David Cobham (Ed.) "The Travails of the Eurozone", Macmillan-Palgrave, London.

Auerbach, Alan J. \& Maurice Obstfeld (2005), "The Case for Open-Market Purchases in a Liquidity Trap," American Economic Review, Volume 95, Issue 1, pp. 110-137.

Barthélemy, Jean, Laurent Clerc \& Magali Marx (2008), “Two-pillar DSGE Monetary Policy Model For the Euro Area," Banque de France, NER-R\#219A.

Beck, Guenter W. \& Volker Wieland (2007), "Money in Monetary Policy Design under Uncertainty: The Two-Pillar Phillips Curve versus ECB-Style Cross-Checking," CEPR Discussion paper No. 6098.

Benhabib, J., S. Schmitt-Grohe \& M. Uribe (2002), “Avoiding Liquidity Traps,” Journal of Political Economy 110, pp. 535-563.

Bernanke, B., T. Laubach, F. Mishkin, \& A. Posen (1999), Inflation Targeting. Princeton, New Jersey: Princeton University Press.

Bernanke, Ben S. \& Blinder, Alan S. (1988), "Credit, Money, and Aggregate Demand," American Economic Review, vol. 78(2), 435-439.

Bernanke, Ben S. \& Frederic S. Mishkin (1997), "Inflation Targeting: A New Framework for Monetary Policy?" Journal of Economic Perspectives 11, no. 2 (spring), pp. 97-116.

Bernanke, Ben S. \& Ilian Mihov (1997), "What does the Bundesbank target?" European Economic Review, Vol. 41, Iss. 6, pp. 1025-1053.

Bordes, C. \& L. Clerc (2007), "Price Stability and The ECB.s Monetary Policy Strategy," Journal of Economic Surveys, Vol. 21, No. 2, pp. 268-325.

Buiter W. H. \& N. Panigirtzoglou (2003), "Overcoming the Zero Bound on Nominal Interest Rates with Negative Interest on Currency: Gesell's Solution,” Economic Journal, 113, pp. 723-746. 
Buiter, W. H. (1984), "Saddlepoint Problems in Continuous Time Rational Expectations Models: A General Method and Some Macroeconomic Examples," Econometrica 52(1), 665-80.

Cabos, Karen, Michael Funke \& Nikolaus A. Siegfried (2003), "Some Thoughts on Monetary Targeting vs. Inflation Targeting," The German Economic Review, Vol. 5, Iss. 3, pp. 219 - 238.

Christiano, Lawrence J., Roberto Motto \& Massimo Rostagno (2007), "Two Reasons Why Money and Credit May be Useful in Monetary Policy," NBER Working Paper No. W13502.

Clarida, R., \& M. Gertler (1996), "How the Bundesbank conducts monetary policy," NBER Working Paper 5581.

Clarida, Richard, Jordi Gali \& Mark Gertler (1998), "Monetary policy rules in practice: Some international evidence," European Economic Review 42, pp. 1033-1068.

Clarida, Richard, Jordi Gali \& Mark Gertler (1999). The Science of Monetary Policy: A New Keynesian Perspective. Journal of Economic Literature, vol. 37, pp. 1661-1707.

Dai, Meixing \& Moïse Sidiropoulos (2003), "Règle du taux d'intérêt optimale, prix des actions et taux d'inflation anticipé : une étude de la stabilité macroéconomique," Économie Appliquée, tome LVI, $\mathrm{n}^{\circ} 4$, p. $115-140$.

De Grauwe, Paul \& Daniel Gros (2009), “A New Two-Pillar Strategy for the ECB,” CEPS Policy Brief No. 191/30 June 2009.

Eggertsson, G.B., \& M. Woodford (2003), "The Zero Bound on Interest Rates and Optimal Monetary Policy," Brookings Papers on Economic Activity, No. 1, 139-211, pp. 230-233.

Evans, George W. \& Seppo Honkapohja (2003) "Friedman's money supply rule vs optimal interest rate policy," Scottish Journal of Political Economy, Vol. 50, pp. 550-566.

Feldstein, Martin \& James H. Stock (1994), "The use of a monetary aggregate to target nominal GDP," in N.G. Mankiw (Ed.), Monetary Policy, University of Chicago Press, Chicago, pp. 7-62.

Friedman, Benjamin. M. (2003), "The LM curve: a not-so-fond farewell," NBER Working Paper ${ }^{\circ}$ 10123.

Gerberding, Christina, Franz Seitz \& Andreas Worms (2005), "How the Bundesbank really conducted monetary policy," The North American Journal of Economics and Finance, Vol. 16, Iss. 3, pp. 277292.

Gerlach, Stefan (2004), "The Two Pillars of the European Central Bank," Economic Policy 40, pp. 389-439.

Goodfriend, Marvin (1983), "Discount window borrowing, monetary policy, and the post-October 6, 1979 Federal Reserve operating procedure," Journal of Monetary Economics 12, pp. 343-356.

Goodhart, Charles A. E. (2007), "Whatever Became of the Monetary Aggregates?" National Institute Economic Review 200, pp. 56-61.

Hess, Gregory D., David H. Small \& Flint Brayton (1993), "Nominal income targeting with the monetary base as instrument: an evaluation of McCallum's rule," Proceedings, Board of Governors of the Federal Reserve System (U.S.).

Ireland, P. (2004), "Money's role in the monetary business cycle," Journal of Money Credit and Banking, vol. 36 (3), pp. 969-84.

Judd, John P. \& Brian Motley (1991), "Nominal Feedback Rules for Monetary Policy," Economic Review, Federal Reserve Bank of San Francisco, Number 3, pp. 3-17.

King, Mervyn (2009), "Speech at the Lord Mayor's Banquet for Bankers and Merchants of the City of London", at the Mansion House. London, England. 17 June.

King, Robert G. (2000), "The new IS-LM model: language, logic, and limits," Economic QuarterlyFederal Reserve Bank of Richmond, issue Sum, pp. 45-103.

Laubach, Thomas \& Adam S. Posen (1997), "Disciplined discretion: the German and Swiss monetary targeting frameworks in operation," Federal Reserve Bank of New York, Research Paper No. 9707.

Mayer, Thomas (2006), "The ECB's monetary policy strategy: Trying to go beyond inflation targeting," Society of Business Economists, Vol. 37, No. 1, pp. 7-21.

McCallum, Bennett T. \& James G. Hoehn (1983), "Instrument Choice for Money Stock Control with Contemporaneous and Lagged Reserve Requirements: Note," Journal of Money, Credit and Banking, Vol. 15, No. 1, pp. 96-101.

McCallum, Bennett T. (1988a), "Robustness Properties of a Rule for Monetary Policy," CarnegieRochester Conference Series on Public Policy 29, pp. 173-204. 
McCallum, Bennett T. (1988b), "Targets, Indicators, and Instruments of Monetary Policy," in: Monetary Policy in an Era of Change, Washington, D. C.: American Enterprise Institute.

Mishkin, Frederic S. (1999), "International Experiences with Different Monetary Policy Regimes," Journal of Monetary Economics, Vol. 43, No. 3, pp. 579-606.

Mishkin, Frederic S. (2002), "From Monetary Targeting to Inflation Targeting: Lessons from Industrialized Countries," in: Banco de Mexico, Stabilization and Monetary Policy: The International Experience (Bank of Mexico: Mexico City), pp. 99-139.

Modigliani, Franco, Robert Rasche \& J. Philip Cooper (1970), "Central Bank Policy, the Money Supply, and the Short-Term Rate of Interest," Journal of Money, Credit and Banking, Vol. 2(2), pp. 166-218.

Romer, D. (2000), "Keynesian Macroeconomics without the LM Curve," The Journal of Economic Perspective, Vol. 14, n 2, pp.149-169.

Rudebusch, Glenn D. \& Lars E. O. Svensson (1999), "Policy Rules and Inflation Targeting," in Taylor, J.B. (Ed.), Monetary Policy Rules. University of Chicago Press, Chicago, pp. 203-246.

Rudebusch, Glenn D. \& Lars E. O. Svensson (2002), "Eurosystem Monetary Targeting: Lessons from U.S. Data," European Economic Review, Vol. 46, Iss. 3, pp. 417-42.

Shirakawa, M. (2009), "Some Thoughts on Incentives at Micro- and Macro-level for Crisis Prevention," Remarks at the Eighth Bank for International Settlements Annual Conference. Basel, Switzerland. 26 June.

Svensson, L.E.O. (1999), "Inflation Targeting as a Monetary Policy Rule," Journal of Monetary Economics 43, pp. 607-654.

Svensson, Lars E. O. (2000), "The First Year of the Eurosystem: Inflation Targeting or Not?" American Economic Review: Papers and Proceedings 90, pp. 95-99.

Svensson, Lars E. O. (2001), "The Zero Bound in an Open Economy: A Foolproof Way of Escaping from a Liquidity Trap," Bank of Japan Monetary and Economic Studies 19, pp. 277-312.

Taylor, John B. (1985), "What Would Nominal GNP Targeting Do to the Business Cycle?" CarnegieRochester Conference Series on Public Policy 22, pp, 61-84.

von Hagen, Jürgen (1999), "Money growth targeting by the Bundesbank," Journal of Monetary Economics, Vol. 43, Issue 3, pp. 681-701.

Walsh, Carl E. (1982), "The effects of alternative operating procedures on economic and financial relationships," Monetary Policy and Issues in the 1980s, Proceedings, Federal Reserve Bank of Kansas City, pp. 133-180.

Walsh, Carl E. (2002), "Teaching Inflation Targeting: An Analysis for Intermediate Macro," Journal of Economic Education 33 (4), pp. 333-347.

Walsh, Carl E. (2003), Monetary Theory and Policy, the MIT Press.

Walsh, Carl E. (2009), "Using Monetary Policy to Stabilize Economic Activity," Paper prepared for the symposium "Financial Stability and Macroeconomic Policy." Jackson Hole, Wyoming. August.

Woodford, Michael (1998), "Doing without Money: Controlling Inflation in a Post-Monetary World," Review of Economic Dynamics 1, pp. 173-219.

Woodford, Michael (2008), "How important is Money in the Conduct of Monetary Policy?" Journal of Money, Credit and Banking, Vol. 40, No. 8, pp. 1561-1598. 


\section{Documents de travail du BETA}

2010-01 The Aggregation of Individual Distributive Preferences through the Distributive Liberal Social Contract : Normative Analysis

Jean MERCIER-YTHIER, janvier 2010.

2010-02 Monnaie et Crise Bancaire dans une Petite Economie Ouverte Jin CHENG, janvier 2010.

2010-03 A Structural nonparametric reappraisal of the $\mathrm{CO}_{2}$ emissions-income relationships Theophile AZOMAHOU, Micheline GOEDHUYS, Phu NGUYEN-VAN, janvier 2010.

2010-04 The signaling role of policy action

Romain BAERISWYL, Camille CORNAND, février 2010.

2010-05 Pro-development growth and international income mobility: evidence world-wide Jalal EL OUARDIGHI, mars 2010.

2010-06 The determinants of scientific research agenda: Why do academic inventors choose to perform patentable versus non-patentable research?

Caroline HUSSLER, Julien PENIN, mars 2010.

2010-07 Adverse Selection, Emission Permits and Optimal Price Differentiation Mourad AFIF, Sandrine SPAETER, mars 2010.

2010-08 The impact of ambiguity on health prevention and insurance Johanna ETNER, Sandrine SPAETER, mars 2010.

2010-09 Equité du plaider coupable : une analyse économétrique dans trois tribunaux de grande instance français.

Lydie ANCELOT, mars 2010.

2010-10 Networks, Irreversibility and Knowledge Creation.

Patrick LLERENA, Muge OZMAN, mars 2010.

2010-11 Les clusters et les réseaux comme fondements de la dynamique d'innovation dans l'industrie biopharmaceutique

Marc Hubert DEPRET, Abelillah HAMDOUCH, avril 2010.

2010-12 Large-scale risks and technological change: What about limited liability? Julien JACOB, Sandrine SPAETER, avril 2010.

2010-13 Innovation and Development. The Evidence from Innovation Surveys

Francesco BOGLIACINO, Giulio PERANI, Mario PIANTA, Stefano SUPINO, avril 2010.

2010-14 Cooperative provision of indivisible public goods

Pierre DEHEZ, juin 2010.

2010-15 Implications de l'imperfection des marchés financiers pour la politique monétaire Meixing DAI, juin 2010. 
2010-16 Bank lending networks, experience, reputation and borrowing costs.

Christophe J. GODLEWSKI, Bulat SANDITOV, Thierry BURGER-HELMCHEN, juin 2010.

2010-17 Les déterminants individuels des absences au travail : une comparaison européenne.

Sabine CHAUPAIN-GUILLOT, Olivier GUILLOT, juin 2010.

2010-18 Fiscal policy efficiency and coordination: The New Open Economy Macroeconomics Approach.

Gilbert KOENIG, Irem ZEYNELOGLU, juillet 2010.

2010-19 Financial market imperfections and monetary policy strategy. Meixing DAI, juillet 2010.

La présente liste ne comprend que les Documents de Travail publiés à partir du $1^{\mathrm{er}}$ janvier 2010 . La liste complète peut être donnée sur demande.

This list contains the Working Paper writen after January 2010, 1rst. The complet list is available upon request. 